JPdK Volume 3 Nomor 1 Tahun 2021 Halaman 80-84

JURNAL PENDIDIKAN dan KONSELING

\title{
Peran Guru Dalam memotivasi Siswa Pada Masa Pandemi
}

\author{
Hasfira $^{1}$, Meisy Marelda ${ }^{2}$ \\ Program Studi Pendidikan Bahasa Inggris \\ Fakultas Ilmu Pendidikan \\ Universitas Pahlawan Tuanku Tambusai \\ Email: hasfirafira19640@gmail.com, meisymarelda05@gmail.com
}

\begin{abstract}
Abstrak
Penelitian ini dilatar belakangi oleh Kesulitan guru dalam memotivasi siswa pada masa pandemi. Tempat penelitian ini dilakukan Di Kuok. sampel penelitian adalah peran guru dalam memotivasi siswa. Subjek penelitian adalah 2 orang guru di kuok. Hasil Penelitian ini bertujuan untuk membahas tentang peran guru dalam memotivasi siswa pada masa pandemi. Pada masa pandemi saat sekarang ini, sebagian besar kegitan dilakukan dirumahdimana guru harus lebih mengupayakan agar minat belajar siswa tidak menurun dengan memberikan metode proses brlajar yangkreatif sehingga siswa bisa lebih bersemangat dalam mengikuti proses pembelajaran. upaya yang bisa diterapkan guru misalnya memberikan metode pembelajaran secara langsung dirumah siswa. Jenis penelitian adalah penelitian kualitatif dimana penelitian ini merupakan sebagai kunci dasar dalam bentuk wawancara untuk memberikan penjelasan tentang bagaimana peran seorang guru agar meningkatkan prestasi siswa dalam kegiatan belajar dan mengembangkan bagaimana siswa lebih mandiri serta lebih bertanggung jawab terhadap tugas yang telah di berikan. Guru harus lebih memperhatikan proses belajar siswa agar dapat menunjang keberhasilan dalam proses pembelajaran. Selain itu guru juga bisa meningkatkan motivasi belajar siswa dengan memberikan penilaian yang sesuai dengan hasil belajar siswa, memberikan apresisasi dalam pencapaian yang dilakukan oleh siswa, dan memberikan kesempatan kepada siswa untuk mengembangkan bakat dan minat yang dimiliki nya. Peran guru sangat berpengaruh terhadap pencapaian yang di raih oleh setiap siswa.
\end{abstract}

Kata Kunci: Metode Pembelajaran, Peran Guru, motivasi

\begin{abstract}
This research is motivated by the difficulty of teachers in motivating students during the pandemic. The place where this research was conducted was at the Bangkinang and Di Kuok Hero University. the research sample is the teacher's role which is lacking in motivating students. The research subjects were 2 teachers in Kuok. The results of this study aim to discuss the role of teachers in motivating students during a pandemic. During the current pandemic, most of the activities are carried out at home where teachers must make more efforts so that students' interest in learning does not decrease by providing interesting and creative learning methods so that students can be more enthusiastic in participating in the learning process. efforts that can be made by the teacher is to provide learning methods directly at students' homes. The research used is a type of qualitative research where this research is a basic key in the form of interviews to provide an explanation of how the role of a teacher is to improve student achievement in learning activities and develop how students are more independent and more responsible for the assignments that have been given. Teachers must pay more attention to the student learning process in order to support success in the learning process. In addition, teachers can also increase student motivation by providing assessments in accordance with student learning outcomes, giving appreciation for the achievements made by students, and providing opportunities for students to develop their talents and interests. The role of the teacher is very influential on the achievements of each student.
\end{abstract}

Keywords: Learning Methods, Teacher Role, Motivation. 


\section{PENDAHULUAN}

Saat ini dunia mulai dihebohkan dengan adanya virus berbahaya, yaitu corona virus disease (covid-19) yang menyerang makhluk hidup. Wabah penyakit ini merupakan virus yang menyebar dengan cepat keberbagai negara salah satunya Indonesia. Dampak dari adanya virus ini sangat berpengaruh terhadap lingkungan mulai dari segi kesehatan, ekonomi, dan pendidikan. Covid ini juga dapat menular dengan sangat cepat Sehingga di setiap daerah pada saat ini melakukan PSBB. Organisasi Kesehatan Dunia (WHO) menetapkan virus corona atau COVID-19 ini sebagai pandemi pada tanggal 11 Maret 2020, Status epidemi global atau pandemi ini menandakan penyebaran COVID-19 berlangsung sangatlah cepat hingga hampir tak ada negara di dunia yang dapat terhindar dari virus corona. Dengan perubahan yang terjadi sekarang maka akan terbentuk sistem baru di bidang pendidikan. Sehingga sistem yang diterapkan di setiap daerah yaitu dengan menggunakan sistem pembelajaran secara online atau daring.

Pembelajaran daring adalah bentuk pembelajaran jarak jauh yang memanfaatkan teknologi, telekomunikasi dan informasi, misalnya internet CD-ROOM (Molinda,2005). Dengan adanya teknologi ini akan memudahkan bagi guru untuk dapat berkomonikasi dengan siapa saja tanpa harus bertemu secara langsung untuk melakukan sebuah interaksi. System tersebut juga sangat membantu kita pada saat melakukan interaksi jarak jauh pada masa pandemi terutama pada proses belajar mengajar menggunakan berbagai aplikasi. Aplikasi yang banyak membantu dalam proses pembelajaran untuk melaksanakan kegiatan secara online yaitu google chrome, youtube, dan whatsapp, dimana antara satu dengan lainnya memiliki fungsi yang berbeda dalam melakukan proses pembelajaran. Di tengah pandemi saat ini proses pembelajaran akan menjadi terhambat karena proses belajar yang seharusnya dilakukan di sekolah secara tatap muka sekarang harus dilakukan di Rumah untuk mencegah terjadinya penyabaran virus corona. Menurut Stein (2020) melakukan social distancing sebagai solusi yang baik untuk mencegah penyebaran Covid-19. Hal ini dapat berpengaruh bagi siswa didik. Oleh karena itu, minat belajar siswa bisa berkembang maka guru harus Suasana pendidikan sebaik mungkin agar setara dengan lingkungan sekolah. Selain itu, motivasi dalam pembelajaran harus dimiliki setiap siswa agar tujuan dalam belajar dapat terwujud dengan baik. proses pembelajaran dilakukan dengan menggunakan system teknologi yang bisa membantu guru dan siswa dalam melakukan proses pembelajaran tanpa bertemu secara langsung.

Pada masa pandemi proses belajar bisa dilaksanakan secara online sangat berpengaruh pada minat belajar setiap siswa, setiap melakukan proses pembelajaran online guru harus melakukan upaya agar siswa nyaman dan bisa menjaga ketertiban didalam kelas asupaya dapat melakukan proses pembelajaran yang terkendali secara baik, karena suasana kelas memiliki dampak yang sangat besar terhadap motivasi belajar siswa. karena itu, pendidik harus mempunyai upaya dalam meningkatkan minat belajar peserta didik yaitu Dengan memberikan cara pembelajaran yang mudah dimengerti oleh siswa, memberikan tugas yang tidak memberatkan siswa, memberikan kesempatan untuk siswa dalam mengembangkan bakat nya, memberikan penilaian yang sesuai dengan kemampuan siswa dan aspresiasi terhadap pencapaian belajar siswa. Berdasarkan hasil penelitian (Marleni dan Asilestari, 2019) pembelajaran daring dapat dilaksanakan dengan menggunakan applikasi online, salah satunya memanfaatkan sosial media. Hal ini sesuai dengan kondisi pandemi yang menggunakan media online sebagai media pembelajaran.

Penelitian yang dilakukan Andaru Werdayanti yang berjudul "Pengaruh Kompetensi Guru dalam proses Belajar Mengajar di Kelas dan Fasilitas Guru terhadap Motivasi Belajar Siswa”. Hasil penelitian menunjukkan bahwa berbagai upaya yang dilakukan guru dalam meningkatkan motivasi belajar adalah menjelaskan tujuan keingin yang harus dicapai, meningkatkan minat pendidik dalam belajar, melaksanakan lingkungan pendidikan yang menyenangkan, menggunakan struktur materi pembelajaran yang menarik, memberikan pujian yang wajar disetiap keberhasilan siswa, memberikan penilaan, memberikan komentar terhadap hasil pekerjaan siswa dan menciptakan persaingan dan kerjasama. Maka dari itu, penelitian ini penting untuk dilaksanakan untuk mengkaji peran guru dalam memotivasi siswa dalam pembelajaran selama pandemi Covid 19.

\section{METODOLOGI PENELITIAN}

Penelitian yang digunakan adalah penelitian kualitatif. penelitian kualitatif adalah penelitian yang bermaksud untuk memahami fenomena tentang apa yang dialami oleh subjek penelitian misalnya perilaku, persepsi, motivasi, tindakan, dan lain-lain secara holistic, dan dengan cara deskripsi dalam bentuk katakata dan bahasa, pada suatu konteks khusus yang alamiah dengan memanfaatkan berbagai metode alamiah. Menurut Bogdan dan Taylor (1972;5) sebagaimana dikutip Moleong mendefinisikan bahwa penelitian kualitatif adalah prosedur penelitian yang menghasilkan data deskriptif berupa kata-kata tertulis atau lisan dari orang-orang dan perilaku yang dapat diamati. Tujuan penelitian kualitatif adalah untuk menjelaskan suatu fenomena dengan sedalamdalamnya dengan cara pengumpulan data yang sedalam-dalamnya pula, yang menunjukkan pentingnya kedalaman dan detail suatu data yang diteliti. Semakin dalam data yang didapat, maka semakin baik kualitas dari penelitian tersebut. Dengan metode penelitian kualitatif akan memudahkan dalam melakukan penelitian tentang peran guru dalam memotivasi siswa pada masa pandemi. Penelitian ini dilakukan di Kec. Kuok, Kab. Kampar, Prov. Riau yang berada di Lintas Sumbar dengan subjek penelitian guru sebanyak 2 orang.

Penelitian ini bertujuan untuk mengetahui peran guru dalam meningkatkan motivasi belajar siswa masa pandemi di Kec. Kuok, Kab. Kampar, Prov. Riau. Penelitian ini juga mengharuskan peran guru untuk memberikan motivasi belajar kepada siswa agar dapat 
menunjang keberhasilan dalam proses pembelajaran. Instrumen penelitian ialah cara untuk memperoleh data yang hakikat nya untuk mengukur variabel penelitian. instrumen penelitian ini dalam bentuk kuesioner. kuisioner ialah pertanyaan yang diajukan kepada guru untuk mendapatkan informasi tentang peran penting pendidik agar bisa memotivasi peserta didik pada masa pandemi. Teknik analisis data adalah suatu metode atau cara untuk memproses Suatu data menjadi informasi sehingga data tersebut menjadi mudah dipahami dan bermanfaat untuk digunakan menemukan solusi dari permasalahan penelitian. Teknik analisis data kualitatif merupakan teknik analisis yang berfokus pada informasi non numerik dengan asas filsafat positivisme. Pada penggunaan teknik analisis kualitatif ini lumrahnya membahas secara konseptual terhadap suatu permasalahan dan tidak terganggu dengan data-data angka.

\section{HASIL PENELITIAN DAN PEMBAHASAN}

Berdasarkan hasil penelitian yang dilakukan, setelah melakukan wawancara bersama salah seorang guru dapat disimpulkan bahwa proses pembelajaran secara online atau daring dapat menurunkan motivasi belajar siswa. Pada saat ini Proses belajar mengajar memang sangat membutuhkan penggunakan akses computer/ media elektronik yang biasa disebut ( Elearning). Menurut Chandrawati.2010 E-learning adalah suatu proses pembelajaran jarak jauh dengan cara menggabungkan prinsip-prinsip didalam proses suatu pembelajaran dengan teknologi. Ada beberapa faktor yang dapat menghambat proses pembelajaran daring misalnya yang pertama ada beberapa peserta didik tidak mempunyai handphone, faktor yang kedua yaitu terhambat nya proses pembelajaran karena jaringan yang tidak stabil, kurangnya modal untuk membeli kuota internet.

Berdasarkan hasil dari wawancara yang telah dilakukan dapat disimpulkan berapa persen (\%) minat belajar siswa yang menurun akibat pandemi covid yang mana proses pembelajaran kini harus dilakukan di rumah dengan metode pebelajaran E-learning.

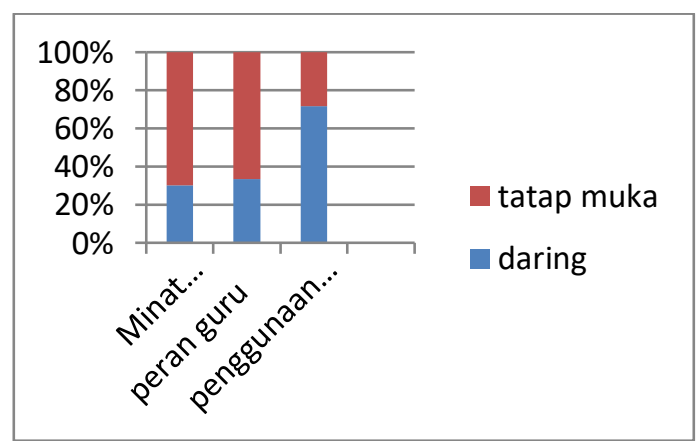

\section{Grafik. 1. Hasil penelitian pada masa pandemi}

Dengan menurunnya proses pembelajaran tersebut guru akan melakukan beberapa upaya salah satunya mendatangi rumah bagi siswa yang tidak memiliki handphone dengan cara memberikam materi pembelajaran secara langsung dan bagi siswa kurang paham terhadap materi yang diberikan maka pendidik membagi peserta didik dalam kelompok belajar untuk membahas materi pembejaran yang kurang paham agar menanyakan kepada temannya yang lebih paham. Pangondian, R.A., Santosa, P I., dan Nugroho, E. (2019) menyatakan banyak kelebihan penggunaan teknologi informasi dan komunikasi dalam pelaksanaan pembelajaran daring diantaranya adalah tidak terikat ruang dan waktu.

Strategi yang dilakukan oleh guru pada pembelajaran online adalah dengan cara membuat grup belajar secara online dan memberikan materi pembelajaran yang memudahkan untuk peserta didik dalam memahami materi yang diberikan. Menurut syaiful Bahri Djamarah," strategi merupakan sebuah cara atau sebuah metode, sedangkan secara umum strategi memiliki pengertian suatu garis besar haluan untuk bertindak dalam usaha mencapai sasaran yang telah ditentukan.

Strategi hampir sama dengan kata taktik, siasat atau politik. Adalah suatu penataan potensi dan sumber daya agar dapat efesien memperoleh hasil suatu rancangan. Selanjutnya, memberikan beberapa pertanyaan untuk memberikan pemahaman kepada siswa dalam berfikir dan memberi tanggapan / jawaban. Proses pembelajaran daring ini juga berdampak kepada motivasi belajar siswa. Terutama siswa yang memiliki handphone karena banyak siswa yang tidak memperdulikan tugas atau pelajaran. Sehingga guru tidak dapat mengontrol agar siswa tidak bermain-main dalam proses belajar. Sebab itu, guru melakukan strategi pembelajaran yang menarik agar siswa tidak merasa bosan saat guru menjelaskan materi pembelajaran.

Banyaknya perubahan yang terjadi akibat pembelajaran daring terutama berdampak bagi siswa dikarenakan banyak siswa yang lengah akibat bermain game, facebook, anime, dan social media lainnya sehingga dapat menurunkan motivasi siswa. Demikian, guru harus pandai untuk meningkatkan motivasi siswa. Menurut Nasution (2010:12) mengemukakan bahwa motivasi anak atau peserta didik adalah menciptakan kondisi sedemikian rupa sehingga anak itu mau melakukan apa yang dapat dilakukan.

Suasana belajar yang nyaman juga bisa membantu untuk meningkatkan motivasi belajar agar siswa lebih aktif untuk menciptakan proses pembelajaran. Motivasi belajar merupakan hal yang berdampak terhadap kegiatan belajar. Dengan adanya minat belajar yang dimiliki oleh setiap siswa akan memudahkan untuk tidak merasa bosan dan lebih bersemangat dalam mengikuti kegiatan belajar.

Pada setiap sekolah pasti memiliki jadwal pembelajaran yang sudah ditetapkan oleh kepala sekolah agar tidak terjadi bentrok saat melakukan kegiatan belajar. Jadwal pembelajaran juga berpengaruh pada cara belajar siswa jika seorang pendidik tidak masuk sesuai jadwal yang ditetapkan, siswa yang awal nya menunggu waktu belajar dengan bersemangat kemudian akan merasa kecewa apabila guru tersebut membatalkan kegiatan belajar secara mendadak. Dengan demikian, pendidik harus masuk sesuai jadwal dan apabila seorang guru ingin membatalkan kegiatan belajar diharapkan agar memberitahukan kepada siswa lebih awal.

Demi terwujud proses pembelajaran dengan baik 
guru harus bisa memaksimalkan waktu yang sudah diberikan agar dapat mendorong siswa lebih menghargai waktu. Dengan proses pembelajaran daring guru juga tetap memberikan penilaian dan apresiasi kepada siswa supaya siswa lebih bersemangat dalam mengikuti kegiatan belajar mengajar dan bisa memberikan motivasi belajar yang lebih baik. Dengan pembelajaran daring bisa menjadikan siswa lebih mandiri agar meningkatkan kemampuan siswa dalam belajar sendiri dan mengajarkan siswa lebih berfikir secara kritis dan inovatif.

Kemampuan yang dimiliki setiap siswa guru harus memberikan apresiasi dan dukungan agar siswa merasa lebih di hargai supaya siswa lebih bersemangat dalam melakukan proses belajar yang dilaksanakan secara mandiri dirumah. Kegiatan belajar yang dilakukan guru harus membuat siswa lebih tertantang agar siswa termotivasi dalam mendapatkan nilai yang tertinggi dalam proses pembelajaran.

Proses belajar daring ini juga bisa melatih untuk siswa agar lebih menghargai waktu dengan membuat jadwal pembelajarannya sendiri. Oleh karena itu, baik guru dan siswa harus bisa saling menghargai waktu yang ditetapkan oleh sekolah supaya proses pembelajaran ini bisa berjalan dengan baik dan siswa paham dengan materi yang diberikan oleh guru. guru juga harus bisa memberikan metode belajar yang mudah dipahami agar siswa tidak merasa kesulitan dalam mengerjakan tugas atau memahami pembelajaran yang telah diberikan.

Kegiatan pembelajaran secara daring juga memiliki beberapa keuntungan yaitu memudahkan bagi siswa dan guru karena dapat dilakukan tanpa adanya terikat terhadap waktu dimana pada proses tatap muka guru wajib untuk masuk kedalam ruangan atau kelas untuk memberikan metode belajar yang telah ditetapkan oleh jadwal pembelajaran yang ada. Pembelajaran online pada pelaksanaannya membutuhkan dukungan perangkat-perangkat mobile seperti telepon pintar, tablet dan laptop yang dapat digunakan untuk mengakses informasi kapan saja dan dimana saja (Gikas dan Grant, 2013).

Menurut Milman (2015) penggunaan teknologi digital dapat memungkinkan mahasiswa dan dosen melaksanakan proses pembelajaran walupun mereka ditempat yang berbeda. penggunaan internet saat ini sangat dibutuhkan bagi siswa maupun guru sehingga bagi siswa yang diberikan materi pembelajaran bisa mencari lebih dalam atau luas informasi melalui gadget atau media informasi lainnya.

Pada masa sekarang ini, Perserta didik dituntut untuk lebih aktif dan mandiri dalam mencari tau materi pembelajaran yang diberikan guru guna menambah wawasan dan informasi secara mendalam guna untuk kepentingan dirinya sendiri karena guru tidak begitu maksimal dalam memberikn materi pembelajaran kebanyakan guru sekarang hanya menjelaskan secara singkat materi belajar oleh karena itu siswa harus lebih pandai dan focus dalam menguasai ilmu pengetahuan untuk mencapai tujuan mereka.

Menurut Mc. Donald dalam Hamalik mengemukakan bahwa motivasi adalah perubahan energy dalam diri seseorang yang ditandai dengan munculnya "feeling" dan di dahului dengan tanggapan terhadap adaalnya tujuan. Sebagai contoh kebanyakan pada masa pandemic ini guru hanya memberikan silabus atau tugas individu maupun pribadi kepada siswa maka dari itu siswa dituntut untuk belajar lebih aktif dalam mencari materi belajar yang ditetapkan. Oleh Karena itu. Penggunaan teknologi sangat diperlukan untuk mencari yang mungkin masih kurang atau belum disampaikan secara detail.

Keberhasilan dalam proses belajar merupakan tujuan utama yaitu dilakukan pendidik terutama dalam meningkatkan motivasi belajar peserta didik. maka seorang pendidik harus bisa memberikan kemajuan bagi siswa untuk giat dalam kegiatan belajar mengajar dengan cara yang mereka sukai dan inginkan. Sabon (2019) menegaskan dalam pembelajaran motivasi merupakan salah satu factor yang mempengaruhi keefektifan dalam kegiatan pembelajaran, karena motivasilah yang mendorong siswa ingin melakukan kegiatan belajar.

Guru juga bisa meningkatkan motivasi belajar siswa dengan cara memberikan tantangan belajar kepada siswa untuk lebih aktif dan bersemangat dalam proses pembelajaran. Rasa gembira penuh semangat, tidak cemas, dan berani mengemukakan pendapat secara terbuka merupakan modal dasar bagi peserta didik untuk tumbuh dan berkembang menjadi manusia yang siap beradaptasi, menghadapi berbagai kemungkinan, dan memasuki era globalisasi yang penuh dengan berbagai tantangan (Mulyasa,2013).

Dalam pencapaian keberhasilan pada proses pembelajaran yang meningkatkan minat siswa bisa juga memiliki dampak yang menyebabkan rendahnya pencapaian dan prestasi belajar. Segala proses pembelajaran hanya menggunakan sumber dari internet yang sangat kurang membantu siswa dalam memahami materi belajar yang sanagat banyak dan bisa membuat siswa banyak fikiran dan tidak maksimal dalam memahami materi pembelajaran yang ada. Dengan demikian, peran guru sangatlah penting dalam memotivasi ssiwa untuk terus giat dalam melaksanakan kegiatan belajar dimanapun dan kapanpun mereka berada dengan cara belajar sendiri yang dilakukan dirumah maupun ditempat yang peserta didik senangi.

Motivasi sangatlah penting ditingkatkan bagi siswa yang malas-malasan dalam melakukan kegiatan pembelajaran terutama pada masa pandemic ini karena tidak ada lagi yang bisa membantu atau mengarahkan peserta didik untuk lebih paham pada materi pembelajaran kalau tidak siswa itu sendiri yang berusaha untuk meningkatkan pengetahuan dalam memahami materi pembelajaran bagi setiap guru. pada pandemic ini guru tidak bisa memberikan arahan secara langsung sehingga siswa dituntut untuk dapat mengarahkan diri masing-masing dengan cara belajar secara mandiri dan teratur guna untuk mencapai keberhasilan prestasi belajar. Selain itu, peserta didik tidak boleh menyerah ataupun mengeluh ketika guru memberikan tugas yang banyak tapi kerjakan setiap tugas yang diberikan guru dengan benar dan tepat waktu 


\section{SIMPULAN}

Berdasarkan penelitian, pada masa pandemi saat sekarang ini proses belajar mengajar yang seharusnya dilakukan secara tatap muka sekarang harus dilakukan secara online atau daring agar proses pembelajaran bisa tetap berjalan dengan baik. Proses kegiatan belajar saat ini sangat memanfaatkan penggunaan teknologi yang ada yaitu Dengan bantuan dari beberapa aplikasi terutama zoom, whatsapp, dan google chrome. Bahwasannya pada saat sekarang ini minat atau motivasi siswa pada masa pandemi sangatlah menurun. Oleh karena itu, Guru harus bisa melakukan beberapa upaya yaitu yang pertama guru harus membangun motivasi belajar siswa untuk diri mereka sendiri.

Selain itu, guru harus memberikan metode pembelajaran yang menarik memberikan suasana belajar yang nyaman agar siswa dapat mengikuti proses pembelajaran agar lebih aktif. karena itu, seharusnya sekolah harus memberikan kuota belajar agar siswa dapat mengikuti kegiatan belajar tersebut. Dengan demikian, upaya guru ini harus bisa terlaksana dengan baik agar siswa lebih nyaman dalam mengikuti kegiatan belajar dan proses pembelajaran yang baik akan membuat siswa lebih memahami materi pembelajaran yang disampaikan oleh setiap guru yang membina mata pembelajaran tersebut.

\section{DAFTAR PUSTAKA}

Adhetya Cahyani, I. D. (2020). Motivasi Belajar Siswa SMA pada Pembelajaran Daring di Masa Pandemi Covid -19. Jurnal Pendidikan Islam, Volume: 3 Nomor:1 Tahun 2020, 18.

Andaru Werdayanti, "Pengaruh Kompetensi Guru dalam Proses Belajar Mengajar di Kelas dan Fasilitas Guru Terhadap Motivasi Belajar Siswa," Dinamika Pendidikan 3, no.1 (2008).

A. S. (2020). Pembelajaran Daring Ditengah Wabah Covid-19. Jurnal Ilmiah Pendidikan Biologi, 11. https://online-journal.unja.ac.id/biodik

E. Mulyasa (2013). Standar Kompetisi Dan Sertifikasi Guru. Bandung: PT Remaja Rosdakarya.

Firman, S. R. (2020). Pembelajaran Online Di Tengah Pandemi Covid-19. Indonesian Journal of Educational Science (IJES), 9.

Gikas, J., \& Grant, M. M. (2013). Mobile computing devices in higher education: student perspectives on learning with cellphones, smartphone \& social media. Internet and Higher Education. https://doi.org/10.1016/j.iheduc.2013.06.002

Hayati, N. (2020). Metode Pembelajaran Daring/ Elearning Yang Efektif. Metode Pembelajaran Elearning, 9.

Marleni, Lusi \& Asilestari, Putri. 2019. Developing Social Media-Based Textbook for Speaking Class in English Study Program. http://ojs.umsida.ac.id/index.php/jees/article/view $\underline{1764}$
Milman, N. B. (2015). Distance Education. In International Encyclopedia of the Social \& Behavioral Science: Second Edition. https://doi.org/10.1016/B978-0-08-0970868.92001-4

Moleong, Lexy. J. 2000. Metodologi Penelitian Kualitatif. Bandung: Remaja Rosdakaya.

Molinda, M. (2005), Instructional Technology and Media for Learning New Jersey Colombus, Ohio

Mona, N. (2020). Konsep Isolasi Dalam Jaringan Sosial Untuk Meminimalisasi Efek Contagious (Kasus Penyebaran Virus Corona Di Indonesia). Jurnal Sosial Humaniora Terapan Universitas Indonesia, 2(2).

Oemar Hamalik. 2004. Proses Belajar Mengajar. (Bumi Aksara: Jakarta.

Sabon, Kosman. (2019). Pengaruh Penggunaan Smartphone Terhadap Motivasi Belajar Siswa Sekolah Dasar Dikecamatan Mapanget Kota Manado. Autentik: Jurnal Pengembangan Pendidikan Dasar. Volume: 3 Nomor:2 Tahun 2019

Stein, R. (2020). COVID-19 and Rationally Leyered Sosia Distancing. Internasional Journal of Clinical Practice. https://doi.org/10.1111/ijcp. 13501

Syaiful Bahri Djmarah, Aswan Zain. Strategi Belajar Mengajar (Jakarta: Rineka cipta. 2002),5

Winditiya Yuliana, M. (2020). Pembelajaran Daring Ditengah Wabah Pandemi Covid-19 Di Universitas Abdurachman Saleh Situbondo. Fakultas Keguruan Dan Ilmu Pendidikan, 8. 